\title{
Relationship between Sleep Stage IV Deficit and Reversible HGH Deficiency in Psychosocial Dwarfism
}

\author{
A. GUILHAUME, O. BENOIT, ${ }^{(28)}$ M. GOURMELEN, AND J. M. RICHARDET \\ Clinique de Pédiatrie, Professeur H. E. Brissaud, Hôpital Trousseau, 75012 Paris, France, [A. G., J. M. R.]; \\ Laboratoire d'Etude du Sommeil, Unité 3 INSERM, 47 Boulevard de l'Hôpital, 75634 Paris Cedex 13, France, \\ [O. B.]; and Laboratoire d'Explorations Fonctionnelles, Prof. F. Girard, Hôpital Trousseau, \\ 75012 Paris, France, [M. G.]
}

\begin{abstract}
Summary
Polygraphic sleep recordings were done in four children with psychosocial dwarfism. The first recordings, performed within the first days after hospitalization, exhibited a gross deficit of stage IV sleep and a decrease of the durations of slow wave sleep episodes (SWS = stages III and IV). The second recordings were performed after several wk (3-15) in the new environment, during the growth recovery period. A clear improvement of sleep quality was observed, namely an increase of stage IV amounts.

In two of the four patients, hGH release was studied by means of the ornithine test. A.low response was found in the first (2) days of hospitalization whereas a normal response was observed during the recovery period suggesting a partial and reversible $\mathrm{hGH}$ deficiency. A simultaneous recovery of both stage IV sleep and the growth rate was observed in the four patients. These data suggest that sleep disturbances are strongly linked to growth failure in psychosocial dwarfism.
\end{abstract}

\section{Speculation}

A reversible hGH deficit has been found in psychosocial dwarfism. A temporal relationship between nocturnal release of hGH and slow wave sleep has already been established by others. We hypothesize that the slow wave sleep deficit observed in our patients can induce a deprivation of considerable amounts of hGH. At this point it is not possible to say whether the functional deficit of hGH is a consequence of the lack of stage $I V$, a reduction of the duration of slow wave sleep (stages III and IV) episodes, or both.

Sleep disturbances of patients with psychosocial dwarfism have frequently been mentioned in the literature $(6,15,17,21)$. In their clinical study. Wolff and Money (26) pointed out a possible relationship between sleep quality and physical growth for patients with reversible somatotropin deficiency. In our paper we present polygraphic sleep data that show a clear relationship between stage IV amounts and physical growth.

\section{MATERIALS AND METHODS}

Four children (three girls and one boy aged 1-3 years) were admitted to the pediatric ward because they had a statural deficit. They all exhibited the main characteristics of psychosocial dwarfism.

Information about social and psychoaffective adjustment were obtained through interviews with parents conducted by the medical, psychologic and social staff members. Physical examination and psychologic testing were completed during the hospitalization. They all had experienced emotional and psychologic deprivation.
I. Clinical data. All four patients had a marked shortness of stature: case A was at the 10th percentile and cases B-D at or slightly below the 3 rd percentile for weight and for length. They also had a delay in skeletal maturation (Table 1). All of them weighed over $3000 \mathrm{~g}$ at birth and had grown normally for periods of time ranging from 6-18 months before their short stature was noted (Fig. 1). Except for staturo-ponderal data, physical findings were in the normal range. Hemoglobins varied from 9-12 g per $100 \mathrm{ml}$. Blood and urine ionograms were normal. Xylose test, fat excretion and small intestinal biopsy were normal in the two cases (A and C) in which they were performed.

Disturbances of behavior were reported in all the cases and were the prime reason for referral in two cases. Feeding difficulties with anorexia were present in cases $A$ and $B$ without any evidence of underfeeding. Poor sleep with frequent awakenings was mentioned for cases C and D. During the first days of hospitalization the four children were very passive, and had immature social responses and withdrawn behavior.

II. Sleep recordings. We obtained two polygraphic nocturnal sleep recordings from each child using a standard methodology. The initial recordings were taken within the first three nights after admission for cases A, B and C and on the ninth night for case D. The second sleep recording for all patients took place 21-102 days later. The sleep stages were visually scored according to the usual criteria (18) adapted to children (2). Slow wave sleep (SWS) was defined as stages III and IV, with the appearance of between 20$50 \%$ of delta waves (without consideration of amplitude) used as the criterion for stage III sleep and above $50 \%$ as that of stage IV. Sleep recordings of twelve nights from ten healthy children of the same age group (1-3 years, mean 2 years) were used as a control.

III. Plasma hGH studies. Three patients (A, B and C) underwent a hGH stimulation test (ornithine load) (8) both in the period of stunted growth and in the recovery period. The test was performed in the first two days of hospitalization for cases $A$ and $B$, but it was carried out only on the ninth day after admission for case $C$. hGH levels were determined by radioimmunoassay (20) with a normal response in the laboratory being defined as a peak plasma $\mathrm{hGH}$ concentration above $11 \mathrm{ng} / \mathrm{ml}(8)$. The mean of the peaks observed in controls after ornithine load is $28 \mathrm{ng} / \mathrm{ml}$ (95\% confidence levels $11-68 \mathrm{ng} / \mathrm{ml}$ ).

\section{RESULTS}

I. Clinical Data. The only therapy used was separating the child from his/her family environment without any special diet or medical intervention. Those behavioral disturbances mentioned by the parents disappeared after a few days in the hospital. The children became happier and more engaged in social communication. All gained 1 or more $\mathrm{kg}$ during the first month after separation from their families. Growth started again shortly after 
Table 1. Growth measurements: initial data

\begin{tabular}{|c|c|c|c|c|c|c|c|}
\hline Case No. & Sex & $\begin{array}{c}\text { Chronologic age } \\
(\mathrm{mo})\end{array}$ & $\begin{array}{l}\text { Height } \\
(\mathrm{cm})\end{array}$ & $\begin{array}{c}\text { Weight } \\
(\mathrm{Kg})\end{array}$ & $\begin{array}{l}\text { Height age } \\
\text { (mo) }\end{array}$ & $\begin{array}{c}\text { Height age } \times 100 \\
\frac{\text { Chronologic age }}{\%}\end{array}$ & $\begin{array}{c}\text { Bone age } \\
\text { (mo) }\end{array}$ \\
\hline A & $\mathbf{M}$ & 12 & 64 & 6.0 & 6.5 & 54 & 10 \\
\hline C & $\mathrm{F}$ & 28 & 73 & 7.2 & 12.0 & 43 & 24 \\
\hline $\mathrm{D}$ & F & 36 & 86 & 10.0 & 26.0 & 72 & 24 \\
\hline
\end{tabular}

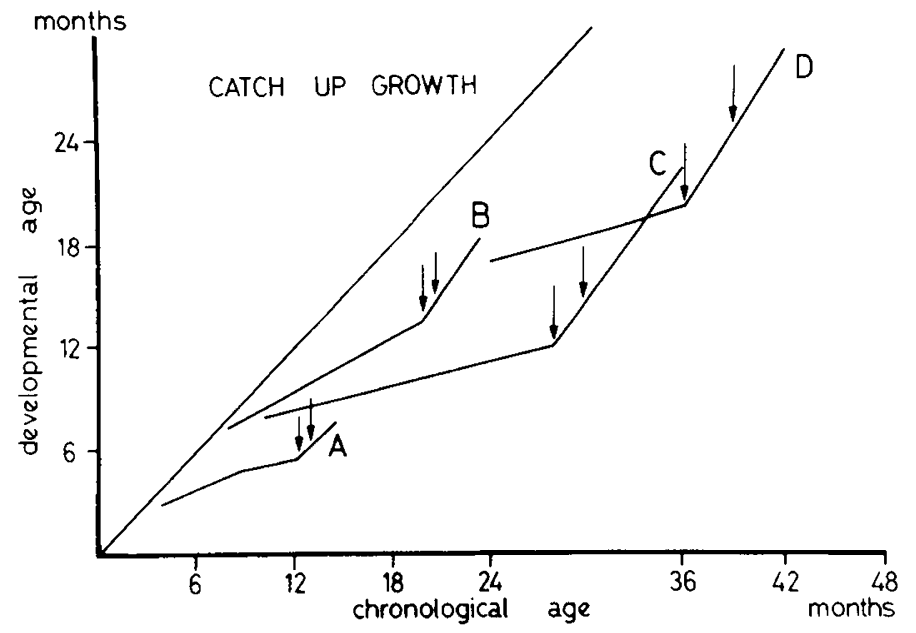

Fig. 1. Individual growth curves (A,B,C, and D): height age is plotted against chronologic age. The normal growth is represented by the solid line at a $45^{\circ}$ angle. Arrows indicate the time of polygraphic sleep recordings. A period of catch-up growth is clearly evidenced between initial and second sleep recordings for each child.

Table 2. Growth data ${ }^{1}$

\begin{tabular}{|c|c|c|c|c|}
\hline \multirow[b]{2}{*}{$\begin{array}{l}\text { Case } \\
\text { No. }\end{array}$} & \multicolumn{2}{|c|}{ Period of sleep disturbances } & \multicolumn{2}{|c|}{ Period of normal sleep pattern } \\
\hline & $\begin{array}{l}\text { Growth } \\
\text { rate } \\
\mathrm{cm} / \text { month }\end{array}$ & $\begin{array}{c}\text { Peak serum hGH } \\
\text { following } \\
\text { ornithine } \\
\mathrm{ng} / \mathrm{ml}\end{array}$ & $\begin{array}{l}\text { Growth } \\
\text { rate } \\
\mathrm{cm} / \text { month }\end{array}$ & $\begin{array}{c}\text { Peak serum hGH } \\
\text { following } \\
\text { ornithine } \\
\mathrm{ng} / \mathrm{ml} \\
\end{array}$ \\
\hline A & 0.33 & 9 & 1.66 & 38 \\
\hline B & 0.58 & 10 & 1.25 & 30 \\
\hline $\mathrm{C}$ & 0.41 & & 1.18 & 20 \\
\hline D & 0.33 & & 0.88 & \\
\hline
\end{tabular}

${ }^{1}$ The average normal monthly rate for this age range is between 0.92 (12-24 months) and 0.71 (24-36 months).

admission as shown by the growth curves (Fig. 1). The growth rates achieved during the 2-9 months of clinical follow-up after being admitted to the pediatric ward were greater than expected for similar chronobiologic ages and represented true catch-up growth (Table 2). Case C has already been published (9).

II. Polygraphic sleep data; initial data: The total sleep period (from sleep onset to morning awakening) was reduced in our patients, and although stage III sleep was of a normal amount, they exhibited a gross SWS deficit as a function of a lack of stage IV sleep. Stage IV was completely absent in three children and in the fourth child (D) it was greatly diminished compared to the controls. For the control group the range of stage IV sleep was between $13.4 \%-30.7 \%$ of the total sleep period (TSP). The control group had $4 \pm 0.4$ (S.E.) SWS episodes ranging from 2-8 per night. Their mean duration was $31.1 \pm 4.5 \mathrm{~min}$ with a range of $8-$ $91 \mathrm{~min}$. Our patients had $2.8 \pm 0.7$ SWS episodes per night with a range of $1-4$. The mean duration of these episodes was $13 \pm 4.8$ min with a range of 2-31 min. Moreover, there was at least one
SWS episode of $26 \mathrm{~min}$ or more for each normal control whereas only one of our patients (D) had episodes of this duration. Interestingly enough, this was the child who was recorded on the ninth day of hospitalization.

The total amount of paradoxical sleep (PS) was decreased in cases B, C and D mainly because of the short duration of the PS episodes (12.1 $\pm 3.5 \mathrm{~min}$ instead of $19.6 \pm 3.2$ in the control group). Individual mean duration of PS episodes ranged from 617 min for our patients and from 10.3-27.2 for the - control children. The sleep efficiency index, $\frac{\text { stages III + IV + Ps (min) }}{\text { TSP - stage } 0 \text { (min) }}$ was decreased in all children (0.14-0.39) when compared to controls (range $0.40-0.58$ ). On the other hand, the ratios $\frac{\text { total sleep time }}{\text { total sleep period }}$ were in the normal range in three children. In case $C$, the amount of intervening wakefulness was very high (Table 3 and Fig. 2A).

In summary, the first sleep recordings after admission exhibited a strongly diminished stage IV and an increased stage I and tendencies to increase intervening wakefulness and decreased PS.

Polygraphic sleep data; sleep recovery: In all of the recordings performed in the recovery period, the TSP for our patients had increased. The sleep parameters neared normal values. The most notable change was the reappearance of stage IV in all of our subjects. Three subjects still had less stage IV than the controls but one subject (D) had a greater amount than normal. The number of SWS episodes increased $(3.3 \pm 0.7 \mathrm{~min})$ and they were of longer duration ( $22 \pm 5.5 \mathrm{~min}$ ) with a range of 2-39 min. In each child there was at least one SWS episode longer than $23 \mathrm{~min}$.

Our patients had nearly normal amounts of PS. The duration of PS episodes increased to $15.7 \pm 5.3 \mathrm{~min}$ with a range of $11.3-$ 18.1. The increase of the sleep efficiency index (Table 3) was accounted for by the recovery of both stage IV and PS. The amount of intervening wakefulness was within the normal range.

$h H G$ levels (Table 2). During the first two days of hospitalization a low response to the ornithine test was observed in both cases $A$ and $B$ ( 9 and $10 \mathrm{ng} / \mathrm{ml}$ respectively) which might indicate a partial $\mathrm{hGH}$ deficiency. When performed during the recovery period, the ornithine test exhibited a normal response $(38$ and $30 \mathrm{ng} / \mathrm{ml}$ ) in both patients. This stimulation test carried out on the ninth day after admission in case $\mathrm{C}$ was normal.

\section{DISCUSSION}

The main features of psychosocial dwarfism, as described in previous reports $(14,15,21)$ were present in our four patients: (1) slowing down in statural growth and in skeletal maturation after the first months of life, and (2) behavioral disturbances and retarded psychomotor development. These symptoms depended upon disrupted relationships between the child and the parents as demonstrated by the rapid reversibility of the symptoms after removal from the familial environment.

Some of the sleep disturbances observed in our patients are frequently found in children with other sleep disorders (2), namely, an increase in stage I sleep and intervening wakefulness and a decrease in PS. But specific to our patients is the striking decrease (case D) or total absence (cases A, B, C) of stage IV sleep. This deficit is particularly impressive when one remembers the usual constancy of SWS in young subjects and the priority of its recovery 

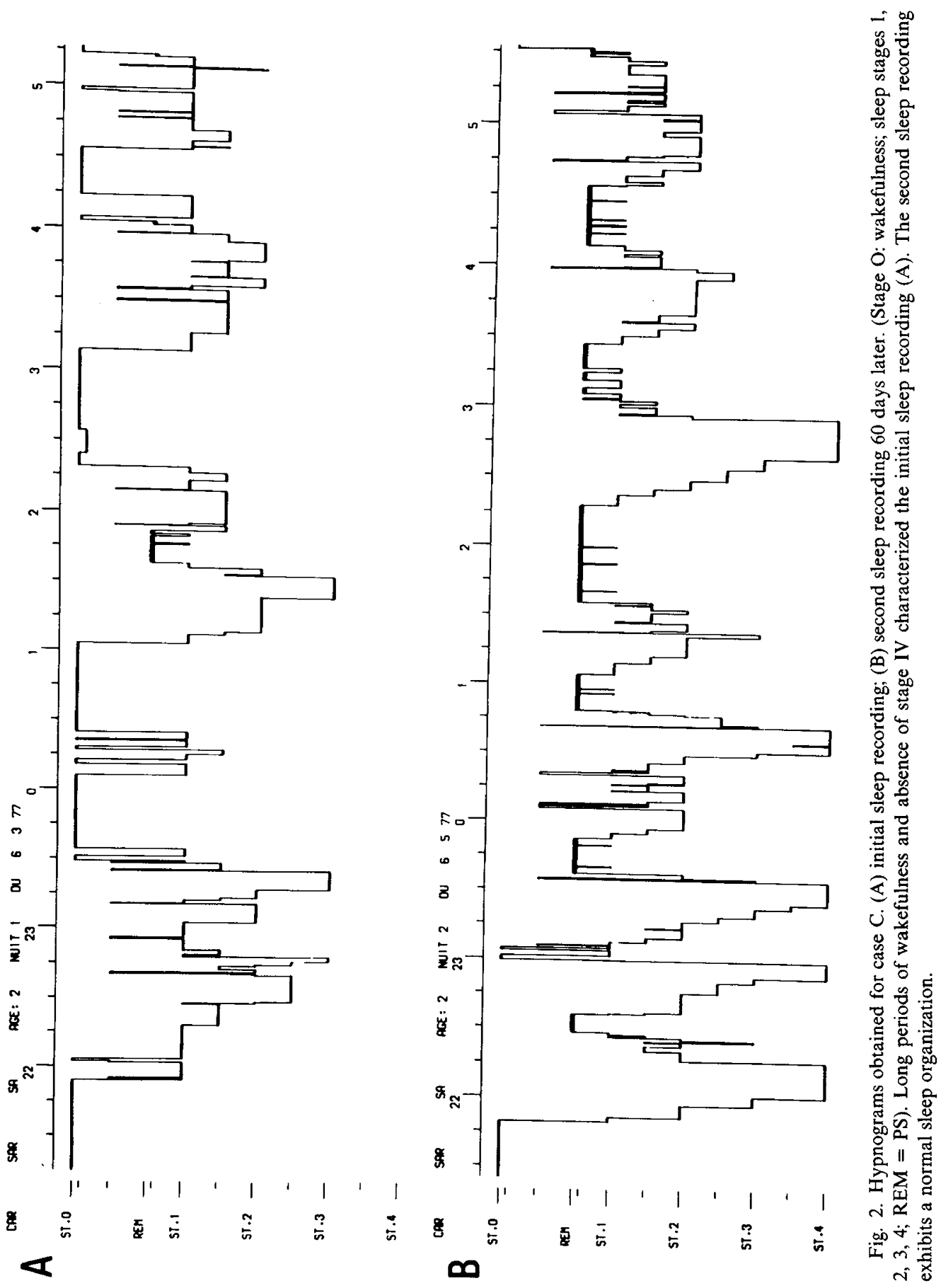
Table 3. Sleep parameters: total sleep period (TSP) and relative amounts of sleep stages (in \% of TSP): intervening wakefulness (W), stages of sleep $(I, I I, I I I, I V)$, and paradoxical sleep $(P S)$ are given for each patient. For our control group the mean values and S.D. are given. The number of days separating the second sleep recording from the first is given for each individual. Mann Whitney tests were performed between patients and controls

\begin{tabular}{|c|c|c|c|c|c|c|c|c|}
\hline & $\begin{array}{c}\text { TSP } \\
(\mathrm{min})\end{array}$ & W & I & II & \multicolumn{2}{|c|}{ S W S } & PS & $\begin{array}{c}\text { Sleep } \\
\text { efficiency } \\
\text { index }\end{array}$ \\
\hline $\begin{array}{l}\text { Normal controls mean } \\
\text { values } \pm \text { S.D. }\end{array}$ & $513.8 \pm 50$ & $4.0 \% \pm 5.2$ & $15 \% \pm 8.4$ & $31.0 \% \pm 6.3$ & $10.4 \% \pm 4.6$ & $18.6 \% \pm 4$ & $21.0 \% \pm 5.8$ & $0.51 \pm .05$ \\
\hline \multicolumn{9}{|l|}{ First recording } \\
\hline Patient A & 400 & $1.5 \%$ & $23 \%$ & $36.7 \%$ & $9.2 \%$ & 0 & $29.5 \%$ & 0.39 \\
\hline Patient B & 417 & 8.2 & 39.3 & 29.6 & 10.6 & 0 & 12.4 & 0.25 \\
\hline Mann Whitney test & $P<0.05$ & NS $(0.10)$ & $P<0.01$ & NS & NS & $P<0.001$ & NS & $P<0.001$ \\
\hline \multicolumn{9}{|l|}{ Second recording } \\
\hline $\begin{array}{l}\text { Patient } A \\
\qquad(+25 \text { days })\end{array}$ & 435 & $2.0 \%$ & $23.7 \%$ & $26.6 \%$ & $15.2 \%$ & $4.8 \%$ & $27.7 \%$ & 0.49 \\
\hline $\begin{array}{l}\text { Patient } A \\
\quad(+21 \text { days })\end{array}$ & 465 & 2.5 & 37.3 & 22.8 & 6.9 & 12.2 & 18.2 & 0.39 \\
\hline Mann Whitney test & $P<0.05$ & NS & $P<0.05$ & NS & NS & NS & NS & NS \\
\hline
\end{tabular}

after sleep deprivation. Total amounts of stage IV or of SWS have a small range of inter- and intra-individual variations in normal situations $(10,24,25)$. And, finally, SWS is not influenced by the first night effect $(1,2)$. Because only night sleep was recorded, a small amount of stage IV during the day cannot be excluded. Nevertheless, it is difficult to imagine that during the day the quality of sleep could compensate for the lack of nocturnal stage IV sleep. In adults, a decreased amount of stage IV has been described in some pathologies such as in the study of Clarke et al. (4). This decrease of stage IV is also often considered the most constant feature of sleep recordings of depressed people $(11,12)$. In fact, the behavior of our patients calls to mind some of the aspects of depression observed in adults. The time necessary for sleep recovery has not yet been studied. But it can be assumed that a certain amount of recovery is achieved within a few days in the new environment: in case D on the ninth day after hospitalization, stage IV represented $9.5 \%$ of TSP. An early recovery might also explain the almost normal SWS amount observed by Powell et al. (17) in a single case of psychosocial dwarfism when recorded on the fifth night after hospitalization.

A slowing down of the growth process, in some cases quite severe, sometimes accompanies these sleep and behavioral disorders when pathologic conditions continue. A complete or partial deficit of hGH after a very early stimulation has been shown to occur in psychosocial dwarfism $(16,17)$. This is exactly what was found in two of the children who underwent the ornithine test within two days of admission to the hospital.

Along with these pharmacologic stimuli of the hGH release, the study of the nocturnal secretion of hGH represents another, more physiologic aspect of control mechanisms (3). Both for normal subjects (23) and those having a partial sleep deficit (5), it has been shown that the nocturnal peaks of hGH are equivalent to those found after pharmacologic stimulation. But nocturnal release of $\mathrm{hGH}$ and diurnal pharmacologic stimulation can give very different results. Some authors (7) have reported an absence of nocturnal peak of hGH in a case of a true hGH deficit, which was responsible for a case of severe dwarfism. In this instance a normal or subnormal response to the pharmacologic hGH stimulation was found. This dwarfism was reversible by means of hGH therapy. Nocturnal release of hGH is known to occur essentially during SWS episodes $(13,19,22)$. SWS alone is not sufficient even though it is necessary for the normal release of hGH $(4,19)$.
Minimal amounts of SWS have been shown to be associated with a blunted hGH response (4) whereas a normal hGH response was noted in all subjects with SWS amounts equal to or greater than 48 min (23).

This part of our work has been little documented and only a prolonged study of the levels of hGH during the entire night could demonstrate such an interaction between SWS and hGH in psychosocial dwarfism. One could hypothesize that in our patients there was an alteration of the night secretion of $\mathrm{hGH}$ because three out of four of them had a total absence of stage IV sleep when hospitalized. This deficit of the physiologic secretion of hGH could have played a role in the slowing down of their growth. It seems that after only a few wk in a new environment the normalization of sleep patterns provided optimal conditions for $\mathrm{hGH}$ release.

To conclude, sleep disturbances, already considered as symptoms of psychosocial dwarfism, might have a causal influence in the growth failure.

\section{REFERENCES AND NOTES}

1. Agnew, H. W., Webb, W. B., and Williams, R. L.: The first night effect: an EEG study of sleep. Psychophysiology, 2: 263 (1966).

2. Benoit, O., Goldenberg-Leygonie, F., Lacombe, J., and Marc, M. F.: Sommeil de l'enfant présentant des manifestations épisodiques du sommeil: comparison avec l'enfant normal. Electroenceph. Clin. Neurophysiol., 44: 502 (1978).

3. Cacciari, E., Coccagna, G., Cicognami, A., Pirazolli, P., Galassi, R., Farnetti, P., Bernardi, F., Zappulla, F., Gobbi, G., and Verucchi, P.: Growth hormone release during sleep in growth-retarded children with normal response to pharmacological tests. Arch. Dis. Child., 53: 487 (1978).

4. Clark, R. W., Schmidt, H. S., and Malarkey, W. B.: Disordered growth hormone and prolactin secretion in primary disorders of sleep. Neurology, 29: 855 (1979).

5. Czernichow, P., Sellem, C., Bailly du Bois, M., and Rappaport, R.: Variations des taux plasmatiques de somathormone au cours du sommeil chez l'enfant normal. Arch. franc. Pédiatr., 29: 1033 (1972).

6. Drash, P. W., Greenberg, N. E., and Money, J.: Intelligence and personality in four syndromes of dwarfism. In: D. B. Cheek, Ed.: Human Growth: Body Composition, Cell Growth, Energy and Intelligence, pp. 568-581. (Lea Febiger, Philadelphia, 1968).

7. Eastman, C. J. and Lazarus, L.: Growth hormone release during sleep in growth retarded children. Arch. Dis. Child., 48: 502 (1973).

8. Gourmelen, M., Donadieu, M.. Schimpff, F. M., Lestradet, H., and Girard, F.: Effet du chlorhydrate d'ornithine sur le taux plasmatique de l'hormone de croissance (hGH). Ann. Endocrin., Paris, 33: 526 (1972).

9. Guilhaume, A., Benoit, O., and Richardet, J. M.: Déficit en sommeil lent profound et nanisme de frustation. Arch. Franc. Pédiatr. 38: 25 (1981). 
10. Hartmann, E., Baekeland, F., Zwilling, G., and Hoy, P.: Sleep need: how much sleep and what kind? Amer. J. Psychiat., 127: 1001 (1971).

11. Hawkins, D. R. and Mendels, J.: Sleep disturbance in depressive syndromes. Amer. J. Psychiat., 123: 682 (1966).

12. Kupfer, D. J.: REM latency: a psychobiologic marker for primary depressive diseases. Biol. Psychiat., II: 159 (1976).

13. Orr, C. W., Vogel, G. W., Stahl, M. L., Griffiths, W. J., and Seely, J. R.: Sleep patterns in growth hormone deficient children and age-matched controls: developmental considerations. Neuroendocrinology, 24: 347 (1977).

14. Patton, R. G. and Gardner, I. L.: Influence of family environment on growth: the syndrome of "maternal deprivation." Pediatrics, 30: 957 (1962).

15. Powell, G. F., Brasel, J. A., and Blizzard, R. M.: Emotional deprivation and growth retardation simulating idiopathic hypopituitarism. I. Clinical evaluation of the syndrome. N. Engl. J. Med., 276: 1271 (1967).

16. Powell, G. F., Brasel, J. A., Raiti, S., and Blizzard, R. M.: Emotional deprivation and growth retardation simulating idiopathic hipopituitarism. II. Endocrinologic evaluation of the syndrome. New Engl. J. Med., 276: 1279 (1967).

17. Powell, G. F., Hopwood, N. J., and Barratt, E. S.: Growth hormone studies before and during catch up growth in a child with emotional deprivation and short stature. J. Clin. Endocrin., 37: 674-679 (1973).

18. Rechtschaffen, A. and Kales, A. Ed.: A manual of standardized terminology, techniques and scoring systems for sleep stages of human subjects. Washington, D.C.: Public Health Service, U.S. Government Printing Office (1968).

19. Sassin, J. F., Parker, D. C., Mace, J. W., Gotlin, R. W., Johnson, L. C., and Rossman, L. G.: Human growth hormone release: relation to slow-wave sleep

Copyright $(1) 1982$ International Pediatric Research Foundation, Inc.

$0031-3998 / 82 / 1604-0299 \$ 2.00 / 0$ and sleep-waking cycles. Science, 165: 513 (1969).

20. Schimpff, R. M., Donnadieu, M., and Combourieu, M.: Dosage radioimmunologique de l'hormone de croissance humaine plasmatique. Path. Biol., 18: 241 (1970).

21. Silver, H. K. and Finkelstein, M.: Deprivation dwarfism. J. Pediatr., 70: 317 (1967).

22. Takahashi, Y., Kipnis, D. M., and Daughaday, W. H.: Growth hormone secretion during sleep. J. Clin. Invest., 47: 2079 (1968).

23. Underwood, L. E., Azumi, K., Voina, S., and Van Wyk, J. J.: Growth hormone levels during sleep in normal and growth hormone deficient children. Pediatrics, 48 : 946 (1971).

24. Webb, W. B. and Agnew, H. W.: Effects of a restricted regime. Science, 150: 1745 (1965)

25. Weitzman, E. D., Kripke, D. F., Goldmacher, D., McGregor, P., and Nogueire, C.: Acute reversal of the sleepwake cycle in man. Arch. Neurol., 22: 483 (1970).

26. Wolff, G. and Money, J.: Relationship between sleep and growth in patients with reversible somatotropin deficiency (psychosocial dwarfism). Psychol. Med., 3: 18 (1973).

27. The authors thank David Roulack and Susan Orsoni for their help with the English version of this manuscript.

28. Requests for reprints should be addressed to: Mrs. O. Benoit, Laboratoire de Physiologie, 91, Boulevard. de l'Hôpital, F-75634 Paris Cedex 13, France.

29. Received for publication March 11, 1981.

30. Accepted for publication August, 198I.

\section{SYMPOSIUM ON THE PREVENTION OF CORONARY HEART DISEASE}

This program is intended for practicing physicians, nurses, physician's assistants, medical students and epidemiologists who are interested in the principles and practice of preventive cardiology.

Dates: $\quad$ May 17 and 18, 1982

Where: University of Iowa Memorial Union

Iowa City, Iowa

Sponsored by: University of Iowa College of Medicine

Preventive Cardiology Academic Award of the National Heart, Lung \& Blood Institute

American Heart Association, Iowa Affiliate

Merck, Sharp and Dome, Educational Grant

Guest Faculty:

Lewis Kuller, M.D.

Donald Riopel, M.D.

William McFate Smith, M.D,

Paul Thompson, M.D.

H. A. Tyroler, M.D.
University of Iowa Faculty:

Arthur Canter, Ph.D.

E. Peter Isacson, M.D.

Ronald M. Lauer, M.D.

James L. Massey, M.A.

Robert E. Rakel, M.D.

Richard M. Schieken, M.D.

Robert B. Wallace, M.D.

Printed in U.S.A.

Course Director:
Credit:

Further information: Ms. Diane Case, Research Assistant, Office of Consultation and Research in Medical Education, W103 CH, University of Iowa, Iowa City, IA 52242 